\title{
Descartes on fermentation in digestion: iatromechanism, analogy and teleology
}

\author{
Carmen Schmechel* \\ Institut für Philosophie, Freie Universität Berlin \\ *Corresponding author: Carmen Schmechel, Email: carmen.schmechel@gmail.com
}

\begin{abstract}
Fermentation is a cornerstone phenomenon in Cartesian physiology, accounting for processes such as digestion or blood formation. I argue that the previously unrecognized conceptual tension between the terms 'fermentation' and 'concoction' reflects Descartes's efforts towards a novel, more thoroughly mechanistic theory of physiology, set up against both Galenism and chymistry. Similarities with chymistry as regards fermentation turn out either epistemologically superficial, or based on shared earlier sources. Descartes tentatively employs 'fermentation' as a less teleological alternative to 'concoction', later renouncing the explicit use of the term, possibly to avoid chymical overtones. However, his continued use of analogies with fermentative processes in the natural world and in winemaking, coupled with a strong ontological commitment (the stance that the physiological processes are actual fermentations), leads to a reintroduction of natural teleology in his medical system, which I argue may be understood in an Aristotelian sense of 'simple necessity'. The paper reveals a more nuanced account of Cartesian fermentative medicine, delineating some of its tensions with regard to chymistry as they play out in the dynamics of fermentation and concoction, and linking the analogies to fermentation processes to the difficulties in erasing teleology altogether.
\end{abstract}

Many scholars have pointed out the importance of fermentation for Cartesian physiology. Annie Bitbol-Hespériès has argued that the fire in the heart is the principle of life for Descartes, which highlights the paramount significance of fermentation as the force that fuels this fire. ${ }^{1}$ In turn, Vincent Aucante notes in La philosophie médicale de Descartes that 'the body is inhabited by various, more or less active fermentations', which cover all the physiological processes of the organism, making fermentation '[1]e moteur des fonctions animales du corps' and 'la pierre d'angle de toute sa physiologie'.

Indeed, Descartes holds fermentation to be central for most physiological processes. ${ }^{3}$ Caution is needed, however, as to how fermentation was defined and understood in this period by different medical writers. Starting around the mid-seventeenth century, 'fermentation' undergoes a major change: from a phenomenon understood in either

\footnotetext{
${ }^{1}$ Annie Bitbol-Hespériès, Le principe de vie chez Descartes, Paris: J. Vrin, 1990, passim.

${ }^{2}$ Vincent Aucante, La philosophie médicale de Descartes, Paris: Presses universitaires de France, 2006, p. 156; Aucante, L'horizon métaphysique de la médecine de Descartes (PhD thesis), Paris: Université de Paris Sorbonne, 1997, p. 165.

${ }^{3}$ Additionally, fermentation also seems to have played a role in Cartesian plant physiology, as recently attested in Fabrizio Baldassarri, 'The mechanical life of plants: Descartes on botany', BJHS (2019) 52(1), pp. 41-63. 
traditional Galenic or alchymical terms, into a more decidedly corpuscular phenomenon that better suited an emerging mechanistic framework in natural philosophy. As Antonio Clericuzio has shown, fermentation as a hypothesis in physiology may in fact have survived thanks to an increased reconceptualization of its workings in terms of corpuscular philosophy, later driven mainly by the circle of Hartlib but initiated, at this scale, by Descartes. ${ }^{4}$

In spite of its centrality for Cartesian physiology, and due at least in part to the Protean quality of the term 'fermentation' and the diverse ways in which it has been appropriated, most of the research landscape has been reluctant in picking up this thread. 'Fermentation', as a term, does not figure in the index of subjects of the Oxford Handbook of Descartes and Cartesianism of 2019, nor in the index of Stephen Gaukroger's English edition of the Treatise on Man, which comprises the texts in which fermentation's role is discussed in more depth by Descartes. ${ }^{5}$ One reason may be, as suggested above, the need to disentangle various concepts of fermentation from one another - a difficult task requiring the joint forces of a conceptual history and a history of practice. Another reason for this reluctance may lie with long-standing epistemological doubts. Could the images that employ fermentation in physiology be mere metaphors - do they have 'a purely rhetorical value', or do they hold epistemic value as well? ${ }^{6}$

This article explores such questions through a closer examination of Descartes's ideas on digestion and blood formation. In describing digestion, Descartes makes use of both 'concoction' and 'fermentation' at different junctures. I argue that his shift from 'concoction' to 'fermentation', as well as a certain measure of reluctance towards both of these terms, reflects Descartes's negotiations with both traditional medical views (as regards concoction) and the newer alchemical ideas (as regards ferments and fermentation). Descartes, as I aim to show, tries to avoid each of these - for different reasons. He uses 'concoction' in 1640 but later renounces it. I propose that the reason for this is that concoction was too redolent of the sort of teleology that he wanted to avoid. He employs 'fermentation' throughout his writings instead, yet he is often reluctant to use the explicit term, presumably in order to avoid associations with the chymical meaning of the ferment as a spiritual agent. As I will show in a comparison of available translations, the fermentative processes he so often invokes are in fact frequently described as 'maturation' (cuver); the 'ferment', often absent in Descartes's original text, is a case of a term literally 'found in translation'.

Fermentations, concoctions and other maturations are shaped by Descartes's relationship with teleology. As is established, one of Descartes's main goals was to do away with inherent final causes in the realm of the natural world. ${ }^{7}$ Within human physiology, he rejects the sentient and the vegetative faculties of Soul (psyché) posed by Aristotle, which were teleological, and replaces them with a different notion: the fire in the heart, the 'principle of life' originating in fermentation, which in turn he explains within a mechanist framework, thus hoping to diffuse any remainders of goal-drivenness. ${ }^{8}$ In

\footnotetext{
${ }^{4}$ Antonio Clericuzio, 'From van Helmont to Boyle: a study of the transmission of Helmontian chemical and medical theories in seventeenth-century England', BJHS (1993) 26(3), pp. 303-34.

${ }^{5}$ René Descartes, The World and Other Writings (tr. Stephen Gaukroger), Cambridge and New York: Cambridge University Press, 1998.

${ }^{6}$ Franco A. Meschini, Materiali per una storia della medicina cartesiana: Dottrine, testi, contesti e lessico, Milan and Udine: Mimesis Edizioni, 2013, pp. 3-175, esp. 65.

${ }^{7}$ See Stephen Gaukroger, 'The resources of a mechanist physiology and the problem of goal-directed processes', in Stephen Gaukroger, John Schuster and John Sutton (eds.), Descartes' Natural Philosophy, London and New York: Routledge, 2003, pp. 383-400; also Annie Bitbol-Hespériès, 'Monsters, nature, and generation from the Renaissance to the early modern period: the emergence of medical thought', in Justin E.H. Smith (ed.), The Problem of Animal Generation in Early Modern Philosophy, Cambridge: Cambridge University Press, 2009, pp. 47-62, esp. 60-1.

${ }^{8}$ See Aristotle, De partibus animalium, 641 a 33 foll., in Aristotle, Parts of Animals. Movement of Animals. Progression of Animals (tr. A.L. Peck and E.S. Forster), Cambridge, MA: Harvard University Press, 1951. For an overview of
} 
contrast to other scholarship, I argue that a Cartesian allegiance to alchemy is, in this particular instance, unlikely. ${ }^{9}$ Descartes's fermentational fire is not alchemical. Rather, it belonged to a shared cultural substrate going back to antiquity. This is not to deny that Descartes might have been influenced by alchemy as regards other ideas. As has been shown, Descartes held transmutation to be possible, and while he repudiated the practices of alchemist forgers, he did not have any aversion towards chymistry as a means of exploring the natural world. ${ }^{10}$ Quite on the contrary, he was intrigued by it. ${ }^{11}$ Notwithstanding, Descartes's concepts of fermentation and heat, to which the discussion in this article is limited, cannot be employed to support the argument of a possible Cartesian allegiance to chymistry.

Although Descartes is very cautious to allow exclusively notions related to the geometry and physical properties of particles to explain fermentation, I argue that it will prove difficult for him to erase the teleological aspect of fermentation. As I attempt to show, part of this challenge is due to the baggage of the idea of fermentation, whose teleology over the centuries may have been less explicit but was nevertheless inherent and pervasive, since the observable results of fermentation were usually, if not always, improved products. This was the case for common practical implementations such as the production of wine in comparison with grape juice, but it also applied to a (presumed) end product such as blood, in comparison with its raw material, the semi-digested food (chyle). Descartes's strong ontological commitment to this analogy - his belief that physiological processes such as digestion were indeed fermentative - means that he imports into physiology the goal-drivenness that fermentations exhibit in the natural world outside the human body. This tendency to understand fermentation teleologically, which I argue has its main roots in daily practices of food production, would later become a selfunderstood feature for Descartes's followers.

\section{Fermentation versus concoction: two problematic terms}

In a 1640 letter to Henricus Regius, Descartes exposes his view on the 'triple concoction' taking place in the human body, with its 'perfect' final outcome - at the end of these three concoctions - being the blood, which arises through a 'pulsific ebullition': the chyme 'in verum \& perfectum sanguinem per ebullitionem pulsificam commutatur'. ${ }^{12}$

Aristotle's doctrine of the faculties of soul see the introduction by A.L. Peck in the same volume, pp. 8-50, esp. 34-7.

${ }^{9}$ A long tradition of thought attempts to link Descartes with alchemy, starting with late seventeenth-century narratives of reconciliation between Cartesianism, Galenism and chymistry. For a broad overview of these contributions see Jean-François Maillard, 'Descartes et l'alchimie: Une tentation conjurée?', in Frank Greiner (ed.), Aspects de la tradition alchimique au XVIIe siècle, Paris: SEHA, 1998, 95-109, esp. 105-8. For the disputed, but not entirely unlikely, influence of Van Helmont on Descartes see G. Monchamp, Histoire du cartésianisme en Belgique, Brussels: F. Hayez, 1886, pp. 89-94; for a recent contribution in this direction see Dorothea Heitsch, 'Descartes, cardiac heat, and alchemy', Ambix (2016) 63(4), pp. 285-303. A nuanced, in-depth view on many aspects of Descartes's relationship with contemporary alchemy is provided, above all, by Bertrand Joly, Descartes et la chimie, Paris: Vrin, 2011. On Descartes's followers and their relationship with alchemy see Sylvain Matton, 'Cartésianisme et alchimie: A propos d'un témoignage ignoré sur les travaux alchimiques de Descartes’, in Greiner, op. cit., pp. 111-84.

${ }^{10}$ See AT IX 653 for an instance of Descartes implying that transmutation is possible; for a discussion of this passage see Maillard, op. cit. (9), p. 102. Examples of disparaging comments regarding the forgers are found in AT I 25, AT I 351, AT III 120, among others.

${ }^{11}$ See AT I 137 (letter to Mersenne).

${ }^{12}$ Letter of Descartes to Henricus Regius, 24 May 1640, AT III 67: '... in præparatione particularum insensibilium ex quibus alimenta constant, ut eæ conformationem humano corpori componendo aptam acquirant. Hæc præparatio alia est communis \& minus præcipua, quæ fit omnibus vijs per quas particulæ transeunt; alia particularis \& præcipua, quæ est triplex: 1' in ventriculo \& intestinis, 2' in hepate, 3' in corde. 1' In ventriculo \& 
'Concoction', a word used since antiquity for a variety of processes, some of them identifiable as common fermentations, was an Aristotelian term. ${ }^{13}$ For Aristotle, "concoction ( $\pi \dot{\varepsilon} \psi \imath \iota$, pepsis) is maturity, produced ... by a thing's own natural heat'. ${ }^{14}$ Afterwards, thanks to the success of Galenic medicine, this term became associated with the traditional description of digestion, which is exactly the sense employed by Descartes. Yet Descartes's thinking about digestion and its inherent concoctions seems to have undergone changes over time, with the account of the threefold concoction being abandoned in the latter half of the $1640 \mathrm{~s}^{15}$ The secondary literature recognizes the problem but does not currently give us a decisive answer to why. Peter Anstey, who addresses the issue more precisely, concludes that Descartes must have 'considered a more sophisticated account of ebullition as non-essential'. ${ }^{16}$

I propose a different hypothesis - that this observed change in Descartes's approach has to do with an intentional shift away from the term 'concoction' and towards an emphasis on the more feasible, for the purposes of mechanism, 'fermentation'. Specifically, I argue that Descartes turned more to 'fermentation' precisely because he believed it would help him to avoid the teleology present in 'concoction', and that this marks a specific development in his thought about digestion and physiology in general.

To underpin this hypothesis, let us examine the use of 'fermentation' in this same letter. First, in the account quoted above, fermentation is the process by which the chyle is digested and transformed into chyme, a process said to take place in the liver: 'In hepate ... chylus ... fermentatur, digeritur, \& in chymum abit.' A few lines later, explaining the same phenomenon, Descartes attracts our attention with a perhaps surprising word choice: 'I say the chyme (juice of the stomach) in its turn is fermented in the liver and digested, that is, exactly as this word is usurped from the Chymists, it is altered by means of a delay. ${ }^{17}$ 'Usurped from the Chymists' ('prout hoc verbum a Chymicis usurpatur'): this is hardly a neutral expression. Instead, it signals Descartes's discomfort with using a new term. Most likely, the 'usurped' term is 'to ferment', or more precisely in this case, 'to be fermented' (lat. fermentari): 'fermentari puto' - 'I claim that it is fermented', or 'I claim it to be fermented'. I take this passage to mean, by paraphrase: the chyme is 'fermented' in the sense in which Descartes's 'Chymists' use this word, meaning entailing an alteration that is due to a delay. This delay was a relatively common feature of sixteenth- and seventeenth-century accounts of fermentation, and it most likely mirrored the everyday experience that any fermentation does not happen instantaneously, instead necessitating a certain time to spread within the mass of the alterandum. Alteration, too, belonged to the conceptual arsenal of the chymists, referring to various changes in matter, including the more special case of transmutations (sanguification being, for medical

intestinis fit, cum cibus ore masticatus \& deglutitus, sicut \& potus, vi caloris à corde communicati, \& humoris ab arterijs eò impulsi, dissolvitur \& in chylum convertitur. 2' In hepate, cum chylus in illud, non per aliquam vim attractricem, sed solâ suâ fluiditate \& pressione vicinarum partium delatus, sanguinique reliquo mixtus, ibi fermentatur, digeritur, \& in chymum abit. 3' In corde, cum chymus, sanguini à reliquo corpore ad cor redeunti permixtus, \& simul cum eo in hepate præparatus, in verum \& perfectum sanguinem per ebullitionem pulsificam commutatur. Atque hæc tertia coctio \&c.'.

${ }^{13}$ Processes subsumed under 'concoction' in Aristotle included the ripening of fruits, the maturation of grapes and processes of digestion. See Aristotle, 379 b 10 foll., in Aristotle, Meteorologica (tr. H.D.P. Lee), Cambridge, MA: Harvard University Press, 1952.

${ }^{14}$ Aristotle, op. cit. (13), 379 b 15.

${ }^{15}$ See Stephen Gaukroger, 'Introduction', in Descartes, op. cit. (5), pp. vii-xxix, xxiv; Peter Anstey, 'Descartes' cardiology and its reception in English physiology', in S. Gaukroger, J. Schuster and J. Sutton (eds.), Descartes' Natural Philosophy, London and New York: Routledge, 2000, pp. 420-44.

${ }^{16}$ Anstey, op. cit. (15), p. 422-3.

${ }^{17}$ AT III 68: 'Chymum autem fermentari puto in hepate, \&digeri, hoc est, prout hoc verbum a Chymicis usurpatur, propter aliquam moram alterari.' 
alchemists, a specific case of transmutation). However, chymistry could hardly claim a monopoly on this term; 'alteration' was a common term related to mixtures and transformations of matter used from antiquity and common in medieval Scholastic writings.

Whether Descartes refers to fermentari or alterari propter aliquam moram as the 'usurped' term, my hypothesis is that here Descartes may have had a sense that he got too close to chemical philosophy by making use of expressions commonly employed in the latter. In this letter to Regius, he still uses 'concoction', a Galenic and Aristotelian term, while cautiously adding 'fermentation' to his arsenal of concepts. It is possible that later in the decade he decides to drop 'concoction' altogether in order to distance himself from those more traditionally minded of his contemporaries who still employed 'concoction' (a majority). The main issue with 'concoction' is that it entailed a strong teleological component ever since Aristotle, where it plays a role in nutrition, but also - more decisively in growth, which rarely fails to act teleologically. 'Fermentation', on the other hand, might have seemed - even as late as 1640 - a term that was gaining ground, but as yet unformed enough to be appropriated by Descartes's mechanical philosophy more easily than it would have been to take 'concoction' and strip it of its long-standing teleology.

Paradoxically, the chymists themselves in the meantime would appropriate the term 'fermentation', gradually implementing its use for processes formerly designated 'concoction'. The extensive use of 'fermentation' in this sense - replacing 'concoction' - was originally Paracelsian, hence not particularly new in the 1630s. Paracelsus, in his turn, had likely drawn inspiration from medieval sources, such as Pseudo-Avicenna's and Roger Bacon's writing on 'ferments' of a spiritual nature that encoded an 'active power'. ${ }^{18}$ But the ones who promoted this particular usage most proactively were indeed the later chymists, such as Joan Baptista van Helmont and Franciscus Sylvius. The chymists' inclination to use 'fermentation' was initially linked to their rejection of traditional Galenic and Aristotelian ideas, which argued that heat and the ensuing concoction were the efficient cause of digestion. Putting forth 'fermentation' was a way of rejecting the joint model of concoction and heat, because this new, spiritualized concept of fermentation did not necessarily involve heat. This was the case for Van Helmont, and it is due to the alchemical tradition of spiritual ferments as formal causes: if transmutation (or any irreversible transformation of matter hence not mere mixtures) can happen solely due to ferments which act as formal causes, then the role of heat is being made redundant. For Van Helmont, who renounced using 'concoction' in a physiological context, digestion was composed of a series of fermentations, each phase with its own specific 'ferment'. ${ }^{19}$ It was those acid ferments, and not heat, which promoted digestion. Descartes, however, is unlikely to have been inspired by Helmontian medicine directly as concerns fermentations, for by contrast to Van Helmont and other earlier chymists, Descartes did assign an important role to heat.

\footnotetext{
${ }^{18}$ For these authors' views on ferments see Sébastien Moureau, 'Elixir atque fermentum: new investigations about the link between Pseudo-Avicenna's alchemical "De Anima” and Roger Bacon: Alchemical and medical doctrines', Traditio (2013) 68, pp. 277-325.

${ }^{19}$ Van Helmont mounted a powerful refutation of the idea of digestion as concoction in Ortus medicinae, his most effective argument being that heat and boiling could never digest food such as bones and liquefy them into chyle. See Jan Baptist van Helmont, Ortus medicinae, id est initia physicae inaudita, 2nd edn (first edn 1648), Amsterdam: apud Ludovicum Elzevirium, 1652, pp. 161-5. On Van Helmont's ideas about digestion see Robert Multhauf, 'J.B. van Helmont's reformation of the Galenic doctrine of digestion', Bulletin of the History of Medicine (1955) 29(2), pp. 15463; Walter Pagel, 'Van Helmont's ideas on gastric digestion and the gastric juice', Bulletin of the History of Medicine (1956) 30, pp. 524-36; more recently, Antonio Clericuzio, 'Chemical and mechanical theories of digestion in early modern medicine', Studies in History and Philosophy of Biological and Biomedical Sciences (2012) 43, pp. 329-37, 332. More generally on how Helmontian fermentation happens see William R. Newman, Gehennical Fire: The Lives of George Starkey, an American Alchemist in the Scientific Revolution, Cambridge, MA: Harvard University Press, 1994, esp. pp. 143-6; Georgiana D. Hedesan, An Alchemical Quest for Universal Knowledge: The 'Christian Philosophy' of Jan Baptist Van Helmont (1579-1644), London and New York: Routledge, 2016, esp. pp. 106-13.
} 
Following Descartes, other later users of the fermentation model would reintegrate heat into their accounts as well; as committed corpuscularians acting within a more established paradigm, their distance from the spiritual ferment tradition enabled them to readopt heat, which can function as an efficient cause of material nature in the absence of any causation of spiritual nature.

Like the chymists, Descartes, too, aimed to distance himself from the ancient medical tradition, which is why a 'fermentation' purged of traditional Galenic overtones appeared more attractive. By and large, in this sense Descartes's endeavour of conceptualizing physiology in terms of mechanical philosophy competed with that of the chymists, whose 'fermentation' carried different overtones, especially a non-material dimension. The two paradigms developed more or less in parallel over several decades of the seventeenth century. A mere handful of authors had employed 'fermentation' in their explanation models for physiology before Descartes; as shown by Clericuzio, these were authors indebted to the chymical philosophy. ${ }^{20}$ Yet in the end, Descartes is as keen to distance himself from the chymical authors as he wishes to break with Galenic medicine.

To sum up, I argue that by using 'fermentation' Descartes attempted to circumvent the traditional teleological component of 'concoction', present ever since Aristotle. He ventured to use a term which, however, came with its own complications: an association with chymistry and a centuries-old teleological baggage. ${ }^{21}$

\section{Descartes, heat and alchemy}

The issue of Descartes and alchemy continues to spark controversy. In the following, I will argue that while Descartes's use of fermentation bears some similarity to contemporary chymical language, either it is a superficial borrowing of a term, or the underlying shared premises can be traced back to common ancient and medieval sources. In both situations it is difficult to make the case for direct influence or inspiration.

To support this stance, I bring three arguments. First, I trace Descartes's reluctance to use the term 'fermentation', ever since the 1630s. Second, I show that Descartes's idea of how exactly fermentation happens differs substantially from that of chymists, in two main respects: the physicality of the process and the role of heat (contrary to the early chymists, Descartes does assign heat a leading role). Third, I show that the heat which chymists do make room for in physiology, and which has been confounded with Descartes's 'fire without light', is a concept of different lineage: its origin is celestial, while Descartes's heat originates in fermentation understood as innate agitation of particles.

First, in Traité de l'homme, Descartes explains how digestion works, portraying it as a physical and fermentative process:

First, food is digested in the stomach of this machine by the force of certain fluids which, gliding among its parts, separate, shake, and heat them, just as ordinary water does those of quicklime, or aqua fortis those of metals. Furthermore these fluids, since they are brought from the heart through the arteries very quickly, must be very hot ... And the food is usually of such a nature that it can be broken down and heated up of itself, just as occurs with new hay if it is shut up in the barn before it is dry. ${ }^{22}$

\footnotetext{
${ }^{20}$ See Clericuzio, op. cit. (19), p. 332. Such authors counted among them Roman physician Pietro Castelli, as well as better-known figures such as Daniel Sennert or Edward Jorden.

${ }^{21}$ This teleological baggage will be embraced by many of Descartes's followers, in resonance with Bertoloni Meli's idea of a more encompassing version of mechanism; see Domenico Bertoloni Meli, Mechanism: A Visual, Lexical, and Conceptual History, Pittsburgh: University of Pittsburgh Press, 2019.

${ }^{22}$ AT XI 121; English translation Descartes, op. cit. (5), p. 100.
} 
Digestion, hence, happens by a process that is analogous to chemical ones, but the explanation for this process is of an exclusively mechanical nature. In the analogy with hay, Descartes refers to what we recognize as a fermentation while avoiding the term itself.

Another instance of unnamed fermentative processes as background for physiology is found in the Discours sur la méthode, where Descartes exposes his theory regarding how God created human beings, first as bodies similar to our own, then placing into the heart a fermentational fire. Here, he repeats the hay analogy and adds another one from winemaking:

I will limit myself to supposing that God formed the heart of a man, fully similar to one of ours ... without putting into him in the beginning any rational soul, nor anything else that would serve as a vegetative or sensitive soul, Apart from enkindling in his heart one of those fires without light that I have already explained, and which I do not conceive at all to be of a different nature than the one which heats the hay when it has been enclosed before it turned dry, or the one which makes new wines seethe when one leaves them to mature on the grapevine shoots. ${ }^{23}$

In this case Descartes places fermentation in an even more crucial position where fermentation processes are made to account for the principle of life. Thus fermentation becomes a cornerstone element in Cartesian medicine and philosophy of nature. Notwithstanding this point, once again he does not name fermentation explicitly.

This omission is an issue which has barely received any attention. ${ }^{24}$ Most translations, in fact, reintroduce the term 'ferment' at the end of this passage, in spite of its absence (though fermentation as we understand it today was certainly part and parcel of the envisioned process). ${ }^{25}$ In my view, however, the glaring absence of the term is most likely intentional on Descartes's part. My hypothesis is that Descartes purposefully circumvents the term, in an attempt to lay the basis for an understanding of fermentation that differed from the chymists' contemporary understanding of it - and hence the philosopher's wish to distance himself accordingly. Consequently, my proposed translation of the above passage differs from the existing ones. On the wines, Descartes simply writes 'on les laisse cuver'; I propose to translate cuver as 'to mature', a term which would have fallen under the semantic realm of the Aristotelian 'concoction'. (This, in turn, raises the issue of natural teleology, which I will address later in more detail.)

\footnotetext{
${ }^{23}$ My translation, from the AT edition. Original: 'Ie me contentay de supposer, que Dieu formast le cors d'vn homme, entièrement semblable a l'vn des nostres ... sans mettre en luy au commencement aucune âme raisonnable, ny aucune autre chose pour y seruir d'âme végétante ou sensitive, Sinon qu'il excitast en son coeur vn de ces feux sans lumière que j'auois desia expliquez, \& que ie ne conceuois point d'autre nature que celuy qui échaufe le foin, lorsqu'on l'a renfermé avant qu'il fust sec, ou qui fait bouillir les vins nouueaux, lorsqu'on les laisse cuuer sur la rape.' AT VI 45-6.

${ }^{24}$ Sylvain Matton mentions in passing that the term for yeast or ferment is not present in L'homme but offers no explanation why. See Matton, op. cit. (9), p. 122 n. 55. Similarly Evan Ragland, in reference to the text of the Passions, in Evan Ragland, 'Mechanism, the senses, and reason: Franciscus Sylvius and Leiden debates over anatomical knowledge after Harvey and Descartes', in Peter Distelzweig, Benjamin Goldberg and Evan R. Ragland (eds.), Early Modern Medicine and Natural Philosophy, Dordrecht: Springer Netherlands, 2016, pp. 173-206, 176.

${ }^{25}$ The English translation in CSMK I 134 renders the last part as 'causes new wine to seethe when it is left to ferment from the crushed grapes'. Another, newer translation by Ian Maclean renders this last part as 'makes new wine rise in temperature, when it is left to ferment on the lees'. Descartes, A Discourse on the Method, a new translation by Ian MacLean, Oxford: Oxford University Press, 2006, pp. 38-39. Maclean's option of 'lees' comes close to the original, except that the lees typically also include other residue that contains yeasts, whereas la rape designates only the grapevine shoots, technically called 'rachis'. Additionally, Maclean's 'rise in temperature' may be more of an interpretation than a translation of bouillir, which in this case seems to refer more to a phenomenon of ebullition and effervescence than to actual boiling; 'seething' seems closest.
} 
Descartes's reluctance towards the term may have a prehistory in his correspondence with Plempius. In an exchange of 1638, Descartes explicitly proposed ferments and fermentation as an explanation model (by analogy) for the beating of the heart. ${ }^{26}$ Plempius, however, unceremoniously held the ferment to be a 'figment', and presumed that Descartes was hard-pressed because there was no other appropriate concept. ${ }^{27}$ Descartes was unpleasantly surprised. ${ }^{28}$ But later omissions of the term may be read as an indication of a reappraisal on his side.

Second, Descartes employs a concept of fermentation different from that held by contemporary chymists, both because it is explained physically (geometrically)-such as digestion described above-and because it does entail heat. We have seen earlier the role of heat being central to the debate on fermentation versus concoction. Traditionally, (Galenic, Aristotelian) concoction could not happen without heat. Alchemists like Van Helmont saw in fermentation a way to reject concoction by saying that fermentation did not necessitate heat, since it was caused by a ferment of spiritual nature. ${ }^{29}$

While Descartes also aimed to set his theory apart from the ancients, he did ascribe a central role to heat in digestion as well as in cardiac movement, fuelled by a 'fire in the heart'. This corresponds to the idea of innate heat (the food being 'heated up of itself'), a concept intimately connected since antiquity with living warm-blooded bodies. ${ }^{30}$ Hippocrates and Aristotle, as well as Galen, considered it fundamental, with Aristotle in particular holding heat to be a result of the action of the vegetative soul. ${ }^{31}$ Descartes, intent as he is on doing away with the vegetative soul, claims that it is the result of fermentations, which hence form 'the first principle and motor of our whole [bodily] machine'. ${ }^{32}$ The fluids heated by fermentation glide in between the parts of the food and break it down, a process reminiscent of Plato's 'cutting' quality of heat in Timaeus. $^{33}$ The breaking down of food by means of their fermentative agitation causes

\footnotetext{
${ }^{26}$ Descartes, To Plempius, 15 February 1638, postulates 'in recessibus cordis nonnihil humoris instar fermenti residere, cuius permistione alius humor adueniens intumescit' (AT I 523); later in the same letter, he explains that the blood remaining in the heart acquires the 'nature of a ferment' ('veluti fermenti naturam') and functions 'after the manner of a ferment' ('fermenti vice', AT I 530). He compares this process to the production of bread and beer (AT I 531). For more on the background of this debate see Lucian Petrescu, 'Descartes on the heartbeat: the Leuven affair', Perspectives on Science (2013) 21(4), pp. 397-428.

27 'I fear that that ferment might be a figment', replied Plempius to Descartes ('fermentum vereor ne figmentum sit'); see AT II 54, also cf. AT I 535.

28 'I am very surprised that you thought the point I made about fermentation was quite far-fetched, and that I was using it as a last resort, as if I were hard pressed, and that point provided the only way of escape. My view can certainly be set out and demonstrated very easily without that point; but even so, it is necessary to admit that some of the blood that is rarefied in the heart remains in it from one diastole to the next, and the rarefaction is increased by the fresh blood that flows in and mixes with it; and the nature and properties of fermentation are clearly relevant to this fact'. CSMK III 96, cf. AT II 69.

${ }^{29}$ This changed in the latter half of the seventeenth century, which is, however, beyond the scope of this article.

${ }^{30}$ Descartes to the Marquis de Newcastle, April (?) 1645, AT IV 289: 'Il me semble que toute la chaleur des animaux consiste en ce qu'ils ont dans le coeur une espèce de feu, qui est sans lumière, semblable à celuy qui s'excite dans l'eau forte, lors qu'on met dedans assez grande quantité de poudre d'acier, \& celuy de toutes les fermentations'.

${ }^{31}$ See Aristotle, De anima (tr. R.D. Hicks), Cambridge: Cambridge University Press, 1907, pp. 65-9, 415 b 6-416 b 25.

${ }^{32}$ Thomas Fuchs, The Mechanization of the Heart: Harvey and Descartes (tr. Marjorie Grene), Rochester, NY: University of Rochester Press, 2001, p. 127. Reference is made here to AT XI 228; cf. also Discours Part 5, AT VI 46-7.

${ }^{33}$ See Plato, Timaeus (tr. Donald J. Zeyl) in Plato: Complete Works (ed. John M. Cooper), Indianapolis: Hackett, 1997, pp. 1224-91: 'the body with the sharpest edges belongs to fire' (p. 1258); 'Of all the elemental kinds, fire is made up of the smallest parts, and that is the reason it can pass through water, earth and air, and any of
} 
the particles to 'descend gradually toward the passage through which the coarsest of them must exit'. ${ }^{34}$ Thus, as is known, the dynamic distribution of particles of food during the fermentative process of digestion is determined by the geometry of these particles. The coarser ones go downwards and exit, while the more 'subtle' ones move upwards through the liver. ${ }^{35}$ It is true that a similar process of separation of coarser and finer elements is also fundamental for spagyria, the alchemical art. ${ }^{36}$ In alchemy, the separation of the more coarse, impure parts from the purer and lighter ones was the task of the Paracelsian 'internal alchemist', or in Van Helmont's version, of the 'Archeus'. ${ }^{37}$ This separation is a feature of the 'philosopher by fire', philosophus per ignem, the alchemist. ${ }^{38}$ Descartes, however, is unlikely to have at this point been inspired by either Paracelsus or Van Helmont directly; rather, this operation of purposeful separation, as one of the steps that make up the digestive process, was an idea that permeated thinking about digestion both in ancient and in modern views. More likely, it originates in empirical observation of how common fermentations happen, both in nature and in industry, forming the blueprint of a process which alchemy rather inherited than invented. It was so ubiquitous in antiquity that it was used to describe processes as diverse as from the artisanal production of metals and wines to various physiological processes such as blood formation. ${ }^{39}$ These processes, moreover, were put into correlation by analogy. In a famous example, Galen compares digestion and blood formation to the fermentation of wine:

Let us, then, compare the chyle to wine just pressed from the grapes and poured into casks, and still working, settling, fermenting, and bubbling with innate heat. The heavy, earthy part of its residues, which I think is called the dregs, is sinking to the bottom of the vessels and the other, light, airy part floats ... In making this comparison, think of the chyle sent up from the stomach to the liver as bubbling and fermenting like new wine ... and beginning to change into useful blood ... ${ }^{40}$

For Galen, the liver hence transforms the chyle into blood by means of a coction comparable to the fermentation of wine. ${ }^{41}$ While Descartes reduces this to what Aucante calls a

their compounds' (p. 1278); 'The fire cuts up the food' (p. 1280). A comparison of Descartes's approach and the ideas in Timaeus may be found in Joly, op. cit. (9), pp. 129-30.

${ }^{34}$ AT XI 121, English translation from Descartes, op. cit. (5), p. 100.

${ }^{35}$ Descartes, op. cit. (5), p. 100; cf. AT XI 121.

${ }^{36}$ On spagyria and the essentially chymical operation of distillation that pertains to it see Joly, op. cit. (9), p. 137.

${ }^{37}$ On this operation of separation in alchemy see W. Kühlmann and J. Telle (eds.), Corpus Paracelsisticum, 1, 2001, p. 284.

38 On Paracelsus and his forging of the term spagyria see Didier Kahn, Alchimie et paracelsisme en France à la fin de la Renaissance (1567-1625), Geneva: Droz, 2007, p. 17; William R. Newman and Lawrence Principe, Alchemy Tried in the Fire: Starkey, Boyle, and the Fate of Helmontian Chemistry, Chicago: The University of Chicago Press, 2005, p. 55; Urs Leo Gantenbein, 'Separatio puri ab impuro: Die Alchemie des Paracelsus', Nova Acta Paracelsica, NF 11, Bern: Lang, 1997, pp. 1-59, 42.

${ }^{39}$ Aristotle, Meteorologica, Book IV contains a description of steel production which includes phases of separation of dross to obtain a purer material: 'this is the way in which steel is made. For the dross sinks to the bottom and is removed from below, and by repeated subjection to this treatment the metal is purified and steel produced ... the better the quality of the iron the smaller the amount of impurity'. Aristotle, op. cit. (13), 383 a 30.

${ }^{40}$ Galen, On the Usefulness of the Parts of the Body: De usu partium. Translated from the Greek with an Introduction and Commentary (tr. Margaret Tallmadge May), Ithaca, NY: Cornell University Press, 1968, pp. 205-6.

${ }^{41}$ See a helpful comparison table in Aucante, La philosophie médicale de Descartes, op. cit. (2), p. 154, where Descartes's hypotheses are juxtaposed with ancient ideas. See also Descartes, AT XI, 123, 3-8. 
'processus purement physique', he is describing roughly the same process (or 'workflow', to use a contemporary term), but explaining its causes differently. ${ }^{42}$

Third, the conceptual origin of Descartes's 'fire without light' has been subject of controversies, being recently deemed alchemical. ${ }^{43}$ Was, then, Descartes's fire (heat) inspired by that of the alchemists? I would argue that this is not the case, since the nature of Cartesian fire was elemental, not celestial like the innate heat of the alchemists. Moreover, the idea to place this fire in the heart, while also employed by alchemists, was part of a common repository of ancient ideas.

For Fernel, as well as for the seventeenth-century alchemists who followed him, innate heat - different from elemental fire - had its source in celestial bodies such as the sun. ${ }^{44}$ This does not mean that the heat of the body comes to it from the outside (which would be understood as 'external heat'), but rather that the body's innate heat is related to solar heat by its nature. But while Fernel claimed that he was deriving his theory from Aristotle, the Stagirite had been ambiguous about the origin of vital heat. ${ }^{45}$ As Gad Freudenthal has shown, Aristotle's animal heat was not of celestial origin; rather, the 'astrologization' of Aristotle's heat came to be with Averroes, and it is likely this line of thought that Fernel and alchemists adopted. ${ }^{46}$ Fernel had hence offered an interpretation of Aristotle through the prism of Arab alchemy. ${ }^{47}$

That Descartes respected Fernel's authority in general is hardly surprising, given the latter's status as one of the most authoritative physicians of the previous century. ${ }^{48}$ Respect, however, need not coincide with agreement. Descartes, as we have seen, held the heat in the body to be a result of fermentations, which he understood as mechanical processes. This view echoes a different Aristotelian suggestion, namely that innate heat might have its source in food, an idea more fully developed by Galen. ${ }^{49}$

In the issue of the ebullition of the blood in the heart, Descartes departs from received notions - both from Fernel and from the scholastics - of the pulsation of the heart being

\footnotetext{
${ }^{42}$ Aucante, op. cit. (2), p. 155. For the term 'workflow' employed to describe a defined sequence of acts in practical knowledge, see Matteo Valleriani (ed.), The Structures of Practical Knowledge, Berlin: Springer 2017 , p. 1.

${ }^{43}$ Heitsch, for instance, argues that Descartes based his physiological theory 'on alchemical and natural philosophical notions of fire and light expounded by precursors and contemporaries who included Jean D'Espagnet, Jean Fernel, Jan Baptist van Helmont, and Andreas Libavius'. Heitsch, op. cit. (9), p. 285.

${ }^{44}$ On innate heat for Fernel see Book IV in J.M. Forrester (ed.), The Physiologia of Jean Fernel (1567), Philadelphia: American Philosophical Society, 2003, pp. 256-302.

${ }^{45}$ The Aristotelian text in question is 736 b-737 a: 'this substance [pneuma which is in the male semen and makes it hot] is analogous to the element which belongs to the stars'. Aristotle, Generation of Animals (tr. A.L. Peck), London: William Heinemann, 1943. For a discussion of this see Everett Mendelsohn, Heat and Life, Cambridge, MA, Harvard University Press, 1964, p. 24.

${ }^{46}$ Gad Freudenthal, 'The medieval astrologization of Aristotle's biology: Averroes on the role of the celestial bodies in the generation of animate beings', Arabic Sciences and Philosophy (2002) 12(1), pp. 111-37, passim.

${ }^{47}$ This is also Hirai's argument, who sees in Fernel's approach a 'lecture platonisante d'Aristote'. See Hiro Hirai, 'Alter Galenus: Jean Fernel et son interprétation platonico-chrétienne de Galien', Early Science and Medicine (2005) 10(1), pp. 1-35, esp. 28.

${ }^{48}$ Fernel was the one to introduce the word 'physiology'; his works - a compendium on physiology in the mid-sixteenth century (1542, reprinted as Physiologia in 1567), as well as the earlier composed De abditis rerum causis - will be generally held in high regard at least until Harvey.

${ }^{49}$ In De respiratione Aristotle writes, 'Further, how are we to describe this fictitious process of the generation of heat from the breath? Observation shows rather that it is a product of the food' (473 a 10). However, elsewhere he seems to argue for a source, an 'agency', of heat that acts upon food but is innate in animal bodies: 'Everything that grows must of necessity take food. This food is always supplied by fluid and solid matter, and the concoction and transformation of these is effected by the agency of heat.' Aristotle, op. cit. (8), 650 a 5. Yet Aristotle gives us no hint as to the nature of this agency. As for Galen, multiple examples of this stance from Galen's writings are found in C.-E.A. Winslow and R.R. Bellinger, 'Hippocratic and Galenic concepts of metabolism', Bulletin of the History of Medicine (1945) 17(2) pp. 127-37, 129.
} 
governed by a vital faculty that manages the heat; instead, Descartes posits that the pulsific movement comes from fermentation alone..$^{50}$ As he writes in the letter to Plempius in reference to cardiac movement, 'there is a sudden expansion and as it were boiling up of the blood in the heart. And what, I ask you, could cause a greater or more sudden change in a body than just such a boiling up and fermentation? ${ }^{51}$ For Descartes, therefore, physiological heat (the 'fire without light') is elemental, not celestial, and in this respect it differs from alchemical ideas of innate heat.

As for the main location of the innate heat being in the heart, while the idea was also entertained by Fernel, it looks upon a long tradition stretching back into antiquity. ${ }^{52}$ It is in accordance with Plato's Timaeus and with the author of the Hippocratic treatise on the heart (Peri kardies). ${ }^{53}$ Aristotle even compares the heart, as a source of heat, to, 'as it were, a hearth, where that which kindles the whole organism shall reside'. ${ }^{54}$ Later, Galen fully embraced the idea, and in On Anatomical Procedures he called the heart 'the seat of passion and source of "innate heat". ${ }^{5}$ This is not to be taken as an indication that Descartes's inspiration would necessarily come directly from these particular ancient sources, but rather that this idea is part of a much older repository that he shares with all of his contemporaries, including the alchemists.

\section{The perils of analogy: importing natural teleology into physiology}

Descartes notoriously rejects teleological explanations of non-living as well as living bodies, insofar as they are devoid of mind; yet his relationship with teleology is not straightforward. ${ }^{56}$ As his apprehension regarding 'concoction' shows, he hoped to avoid its teleology. Instead, he employed 'fermentation' at a crucial joint of his argument: he placed 'fermentation', conceived mechanistically, in a position to replace 'concoction' as well as the traditional 'souls' of Aristotelianism and Galenism. But was 'fermentation', in this lifesustaining role, a viable candidate for Descartes to be able to eliminate teleology from physiology? More specifically, can Descartes reconcile the natural teleology inherent in 'fermentation' with his concept of a non-teleological living body? I argue that this is only partially the case.

Some background is necessary. In recent years, scholars such as Stephen Gaukroger, Karen Detlefsen and others have significantly advanced our understanding of Cartesian teleology as it applies to living systems. Detlefsen recognizes that 'Descartes routinely makes use of teleological-sounding explanations in his biological works' and that this creates tension in Descartes's philosophical system. ${ }^{57}$ She claims that for Descartes 'living bodies - human or other - have no teleological natures at all, and so the teleologicalsounding explanations that Descartes uses in his biological works pose an insurmountable

\footnotetext{
${ }^{50}$ See Etienne Gilson's framing of this issue in his Etudes sur le rôle de la philosophie médiévale dans la formation du système cartésien, Paris: J. Vrin, 1951, p. 63.

${ }^{51}$ Descartes to Plempius, 15 February 1638, AT I 531; translation from CSMK III 84.

52 Gilson, op. cit. (50), p. 58 ff.

${ }^{53}$ F.M. Cornford, Plato's Cosmology: The 'Timaeus' Translated with Commentary, New York: Routledge, 1935, p. 314; Frank R. Hurlbutt, 'Peri kardies: a treatise on the heart from the Hippocratic corpus. Introduction and translation', Bulletin of the History of Medicine (1939) 7(9), pp. 1104-13, esp. 1111, 1113, Peri kardies V, VI, XII.

${ }^{54}$ Aristotle, op. cit. (8), 652 b 20-30 and 670 a 23-6. See also 678 b 1 on 'blooded animals': 'the only organ they must necessarily have is the counterpart of the heart, since the sensitive part of the Soul and the original cause of life is always situated in some place which rules the body and its parts'.

${ }^{55}$ Galen, On Anatomical Procedures (tr. C. Singer), London: Oxford University Press, 1956, p. 184.

${ }^{56}$ See, among others, Gaukroger op. cit. (7).

${ }^{57}$ Karen Detlefsen, 'Teleology and natures in Descartes' Sixth Meditation', in Detlefsen (ed.), Descartes' Meditations: A Critical Guide, Cambridge: Cambridge University Press, 2013, pp. 153-74, esp. 153.
} 
difficulty for him'. ${ }^{58}$ The form that teleology takes in Descartes is, Detlefsen proposes, Aristotelian (broadly, 'natural' teleology): 'Aristotelian teleology is an immanent or intrinsic teleology according to which the goal or end is intrinsic to the being itself, which thus has an internal, end-directed principle of change. The being need not be conscious or aware of this intrinsic end. ${ }^{59}$ In turn, Alison Simmons's view, as summarized by Detlefsen, is that Descartes 'does take the mind-body composite to be a teleological system', thereby adopting a 'natural teleology' in the medieval sense of 'the attribution of ends to non-rational bodies and their parts'; this version is 'perfectly legitimate in Descartes' philosophy', covering situations such as digestion and other physiological processes. ${ }^{60}$ Therefore, for both scholars, teleology sits rather uncomfortably in Descartes's physiology, its role being reduced to supporting the end goal of the survival of the mind-body composite.

However, Simmons and Detlefsen, as well as Gaukroger, argue that teleology for Descartes is not to be found in human bodies as such, isolated from the mind - that is, in any living bodies in general when considered apart from the mind, "because such systems are composed merely of matter which is moving in accordance with descriptive laws of nature'. ${ }^{61}$

My findings show that Descartes consistently allows for a type of natural teleology in living human bodies, not taken as wholes but, specifically, in their partial processes which make up the physiological functioning, and in particular in digestion which is conceived of as a teleological process. I address this with regard to the gradual refinement of chyle up to the stage of blood formation, discussed in the context of an analogy with fermentation in the natural world.

Descartes explains in the Cogitationes, 'Quod subtilius est, celerius movetur' ('what is more subtle, moves at greater speed'). ${ }^{62}$ Yet not only speed, but also the ensuing direction of particles of matter, turns out to be a function of their dimensions, since direction is a result of the interaction between the geometry of the particles themselves and of the vessels through which they flow. That direction is necessarily determined already through geometry need not speak for goal-directedness, since the causation goes the other way around; however, we know that these movements of chyle and blood typically only go in one direction of the digestive 'workflow', with the culmination consisting in the formation of new blood and spirits. So, too, for Descartes in L'homme:

the pores of the liver are arranged in such a way that this fluid, on entering, is refined and transformed [s'y subtilise, s'y elabore] taking on the colour and form of blood, just as the white juice of black grapes is converted into light-red wine when it is allowed to ferment [cuuer - 'to mature'] on the vine stock. ${ }^{63}$

The image used as an analogy, the maturation of grapes during vinification, contains its own unidirectionality and also teleology: the grapes turn into wine (and never the other way around); maturation is usually - and certainly so in the case of winemaking - understood as a goal-driven process, where the goal is the end product. This would parallel the

${ }^{58}$ Detlefsen, op. cit. (57), p. 169.

${ }^{59}$ Detlefsen, op. cit. (57), p. 157.

${ }^{60}$ This is discussed in Detlefsen, op. cit. (57), p. 155.

${ }^{61}$ See Detlefsen, op. cit. (57), pp. 154, 162.

${ }^{62}$ Descartes, Cogitationes [4], AT XI 507, 1.

${ }^{63}$ Original in AT XI 123. Source of English translation (from which I distance myself as to the 'ferment' issue): Descartes, op. cit. (5), p. 101. See AT XI 123: 'tout ainsi que le suc des raisins noirs, qui est blanc, se conuertit en vin clairet, lors qu'on le laisse cuuer sur la raspe'. The 'ferment' is an added interpretation; Descartes writes solely of maturation. 
Aristotelian final cause, described as 'that for the sake of which the thing is formed - since that is the logos of the thing - its rational ground, and the logos is always the beginning for products of Nature as well as for those of Art. ${ }^{64}$ This seems quite applicable to spontaneous fermentations (found both in nature and in the human body, as accords with a seventeenth-century understanding of physiology). ${ }^{65}$

But the Cartesian quote above may be an even better illustration of another Aristotelian concept: that of necessity. To say that the geometry of the hepatic pores is arranged in such a way as to direct the fluid towards its ameliorative transformation is akin to what Aristotle would have called the causation by 'simple' necessity, present in natural objects. This he called 'a third mode of Necessity', 'seen in the things that pass through a process of formation'. 66 'Necessity' was an extension, a side note on his system of causes in the natural world; whereas the 'final cause' carries most weight, some 'things come to be by necessity, and so their causes must be referred back to the matter and to the source which initiated their movement' (i.e. the material and the motive cause). ${ }^{67}$ Aristotle specifically used a physiological process, respiration, to illustrate how necessity works:

We point out that although Respiration takes place for such and such a purpose, any one stage of the process follows upon the others by necessity. Necessity means sometimes (a) that if this or that is to be the final Cause and purpose, then such and such things must be so; but sometimes it means (b) that things are as they are owing to their very nature, as the following shows: It is necessary that the hot substance should go out and come in again as it offers resistance, and that the air should flow in ... ${ }^{68}$

We must note that the causation described above may go both ways: sometimes the final cause determines the shape of things (because an axe must chop wood, it will be made of hard material), but other times the very nature of things determines the course - such as in Aristotle's biological example.

For Descartes this applies similarly: (a) if formation of blood has to be the end goal of digestion, then the chyle has to undergo processes of refinement; if the fluid entering the liver is to be subtilized, the pores of the liver need to be shaped a certain way; (b) other times, because matter is in a certain way, it is led towards certain ends: due to matter being subtle and hot, it is led towards fermentation, which in turn causes the rarefaction and the formation of blood. Thus Descartes's account of physiological fermentation turns out to parallel some of Aristotle's ideas about causation and necessity.

The processes undergone by the crushed grapes, as well as by fresh, moist hay, are indeed both instances of what we would also call fermentation today. Descartes, as well as many of his contemporaries, used analogies like those referring to fermentations (maturations) to describe physiological phenomena. In the original texts, I have found a stronger reference (than in the available translations) to practices of vintage that were well known to his contemporaries, such as when the grapes were left to ferment

\footnotetext{
${ }^{64}$ Aristotle, op. cit. (8), 639 b 11.

${ }^{65}$ If, by contrast, we think of winemaking as an artisanal or industrial process, this would be a different kind of teleology, having to do with an external agent's intention (the vintner's idea of wine); Detlefsen classifies similar instances as a Platonic type of teleology. For an explanation of Platonic teleology as it relates to Descartes see Detlefsen, op. cit. (57), p. 157.

${ }^{66}$ Aristotle, op. cit. (8), 642 a 2.

${ }^{67}$ Aristotle here refers to secondary characteristics in animals, such as eye colour. Aristotle, op. cit. (45) (De generatione animalium), $778 \mathrm{~b} 1$. Another version of this argument is to be found in De partibus animalium: 'the action and its organ are there simply because the presence of others necessarily involves them' (645 b 32).

${ }^{68}$ Aristotle, op. cit. (8), 642 b 1, my emphasis.
} 
together with the grapevine shoot, the rachis. The expression used by Descartes is sur la rape, or, as it appears in L'homme, raspe-identifiable as râpe or rafle. This is a technique which results in a vendange entière, giving the wine a toastier aroma; while it is rather rare today, as most vintners remove all the stalks mechanically in a process called éraflage, it may have been more popular in Descartes's time. ${ }^{69}$ By referring to the grapes maturing on the rachis, Descartes underlines the natural process, with as little human intervention as possible (the step of mechanically removing the stems being omitted). The analogy with an almost naturally occurring process enables Descartes to argue that the tendency to ferment is inscribed in the blood itself, the fermentational fire in the heart paralleling the one that emerges naturally when grapes are left to mature on their own.

In this manner, a hint of teleology from the natural world has found its way into Descartes's description. Traditionally, too, the formation of blood has been the end product of a series of fermentations, the last one usually being located in the liver (just as Descartes places it), and it is undisputed that the formation of new blood was a culmination of these processes of gradual refinement. It becomes quite difficult, if not impossible, for Descartes to circumvent teleology here altogether with regard to the human body, because the directionality is transferred from the fermentation model. In fact, Detlefsen also admits that Descartes might have introduced teleological function for the body-in-isolation, in his biological works such as Treatise on Man:

The living human body alone is able, through mechanical means, to achieve a great number of biological functions, including those which contribute to its continued unity, its continued life, and its self-preservative behaviors ... the very teleological features supposedly realized by the presence of the soul. ${ }^{70}$

Yet she does not confer on that sort of teleology a full status, suggesting instead that what Descartes might rely on is 'quasi-teleological accounts of biological processes in all living things' ${ }^{71}$ A similar stance is found in Gaukroger, who writes of an 'apparent goaldirectedness of certain physiological processes' (which nevertheless 'is the most serious challenge to a mechanist physiology'). ${ }^{72}$

When Descartes writes that the chyle is 'refined and transformed', while this still happens by mechanical means, it remains a process with a clear direction. ${ }^{73}$ Accordingly, I would like to nuance Thomas Fuchs's claim that fermentation is not an ennobling process for Descartes. ${ }^{74}$ It is difficult to argue that the subtilized and elaborated products of physiological fermentations, such as blood and spirits, would not be superior to masticated food, if we consider a system of causation in which the final cause has ontological

\footnotetext{
${ }^{69}$ Information on the meaning of la rape in winemaking was kindly provided by Raphaël Mariani, attaché de conservation du patrimoine du Musée Unterlinden, Colmar, in private correspondence.

${ }^{70}$ Detlefsen, op. cit. (57), p. 166.

${ }^{71}$ Detlefsen, op. cit. (57), p. 169, my emphasis.

72 Gaukroger op. cit. (7), p. 385.

${ }^{73}$ If Dennis Des Chene's argument is correct in that 'Descartes treats all directedness toward ends as intentionality', and that there 'can be no directedness toward ends except if those ends are conceived by a mind', then I argue that Descartes is running into a significant issue with fermentation, since he is forced to admit directedness in the refinement of the chyle becoming blood, although there is no intentionality here in the sense of a purpose of a conscious mind. See Dennis Des Chene, Spirits and Clocks: Machine and Organism in Descartes, Ithaca, NY: Cornell University Press, 2001, p. 18 n. I would add that an external intentionality would be closer to a Platonic type of teleology, which Detlefsen claims that Descartes dismisses - see Detlefsen, op. cit. (57), pp. 160-1.

${ }^{74}$ Thomas Fuchs, op. cit. (32), p. 127, writes that 'fermentation, too ... is no longer anything specifically organic or, as it was for contemporary alchemists, a qualitatively ennobling process, but arises merely from the inorganic world of particles'.
} 
priority. I thus argue that Descartes's project of erasing teleology from fermentation was ultimately only moderately successful, and part of the reason may be not just his reliance on analogies with fermentation processes from the natural world, but his stance that the processes happening in the human body are actually fermentative.

\section{Descartes's ontological commitment to the fermentation analogies}

Descartes's fermentation analogies, I argue, carry epistemological weight due to the philosopher's ontological commitment. ${ }^{75}$ In other words, Descartes indeed believes that there are actual fermentations going on in the human body. The fact that these fermentations slightly differ amongst themselves is irrelevant for the issue of their classification in the same group. One could say, with G.E.R. Lloyd, that they belong to the acceptable semantic stretch of the term. ${ }^{76}$ Today we also conceptualize 'fermentation' as having different versions: the fermentation of milk, for instance, is a lactic fermentation, and we know that it is produced by lactic bacteria - different from the fermentation of beer or of bread, which is caused by yeast and is classified as an alcoholic fermentation. Yet we still say that the fermentation of milk is like the fermentation of beer, and what we mean is that while these processes are not identical, we have agreed to categorize both of them as valid 'fermentations'. In a similar way, Descartes and his contemporaries wrote about 'fermentations' in digestion and the rest of physiology, presuming that what happens in the human body during digestion would belong to the same class of natural phenomena to which the observable fermentations of wine or hay were assigned. In that sense, Descartes's analogies of physiological processes and natural phenomena were more than a simple figure of speech. They belonged to a reasoning that could qualify as transdiction, a common early modern device of philosophical-scientific inquiry. As Margaret Osler explains, transdiction is 'a form of inference by which one reasons from the observed properties of macroscopic bodies to the unobservable properties of their microscopic components'. Transdiction was, according to Osler, 'intrinsic to the mechanical philosophy'; however, it was not without its perils. ${ }^{77}$ Its 'problematic character', I would argue, stems from a rather simple fact: one does not, and Descartes did not, possess an exhaustive knowledge of those visible macroscopic phenomena that one deploys to explain the invisible. In early modern Europe, fermentation is a common phenomenon, easily observable in daily life and hence easily lending itself as an analogy for physiological processes. But the efficient cause of fermentation remained unknown - or rather unverifiable - and therefore the object of speculation; hence the perils of employing it as an analogy.

\section{Conclusion}

Within a contemporary framework, this analogy remains, however, intended as epistemologically valuable. The phenomenon of fermentation emerges thus as one of the main

\footnotetext{
${ }^{75}$ For the term of ontological commitment in this particular usage I may refer to Rune Nyord's contribution, 'Analogy and metaphor in ancient medicine and the ancient Egyptian conceptualisation of heat in the body', in John Z. Wee (ed.), The Comparable Body: Analogy and Metaphor in Ancient Mesopotamian, Egyptian, and Greco-Roman Medicine, Leiden and Boston: Brill, 2017, pp. 12-43, esp. 12, 17.

${ }^{76}$ For the concept of semantic stretch see G.E.R Lloyd, Being, Humanity, and Understanding: Studies in Ancient and Modern Societies, Oxford: Oxford University Press, 2012, p. 73 and passim.

${ }^{77}$ Margaret J. Osler, Divine Will and the Mechanical Philosophy: Gassendi and Descartes on Contingency and Necessity in the Created World, Cambridge: Cambridge University Press, 1994, p. 177. On transdiction as a mode of reasoning see also Maurice Mandelbaum, Philosophy, Science, and Sense Perception: Historical and Critical Studies, Baltimore: Johns Hopkins University Press, 1964.
} 
sites where an advancement in scientific understanding of living bodies is negotiated: between Aristotelian-Galenic tradition and mechanist innovation, between chymistry and physics. Thus, for Descartes, everyday practices of fermentation such as the production of wine (or beer, or bread) are valuable sources from which analogies and scientific hypotheses about the human body may be derived. ${ }^{78}$

Acknowledgements. I would like to thank Fabrizio Baldassarri and the participants and organizers of the Medicine in the Philosophy of Descartes conference (Pisa, 2020) where I presented an early draft of this paper. My thanks also go to two anonymous referees of the BJHS who provided valuable feedback, as well as to BJHS editor Amanda Rees and editorial assistant Trish Hatton, who guided this article through the process. Moreover, I owe a debt of gratitude to Glenn W. Most for encouragement and support of the broader historical project that gave rise to this research. Research for this article was generously funded by the German Research Council (Deutsche Forschungsgemeinschaft) under grant agreement No. 432256662.

\footnotetext{
${ }^{78}$ See the references in Letter to Plempius, 15 February 1638, AT I 530-1.
}

Cite this article: Schmechel C (2022). Descartes on fermentation in digestion: iatromechanism, analogy and teleology. The British Journal for the History of Science 55, 101-116. https://doi.org/10.1017/S0007087421000819 